\title{
Occurrence of Polyovular Follicles in Mouse Lines Selected for High Fecundity
}

\author{
Hannelore ALM ${ }^{1)}$, Simone KUHLMANN1), Martina LANGHAMMER ${ }^{2)}$, Armin TUCHSCHERER ${ }^{2)}$, \\ Helmut TORNER ${ }^{1)}$ and Norbert REINSCH ${ }^{2)}$
}

\author{
${ }^{1)}$ Research Unit Reproductive Biology, ${ }^{2}$ Research Unit Genetics and Biometry, FBN Research Institute for the Biology of \\ Farm Animals, 18196 Dummerstorf, Germany
}

\begin{abstract}
The aim of this study was to evaluate the prevalence of follicles with more than one oocyte (polyovular follicles, POFs) in mouse lines selected for high fecundity. The ovaries of 18 mice, 6 each from 3 different lines, were examined to evaluate the number of POFs and the follicular histology. Polyovular follicles were observed in the two high fecundity breeds, FL1 and FL2, as well as in the unselected control line, DUKsi. The highest number of POFs per ovary $(27.0 \pm 7.2)$ was found in the FL1 line. The FL2 and DUKsi lines had $1.9 \pm 0.7$ and $0.6 \pm 0.3$ polyovular follicles per ovary, respectively. Most of the POFs contained 2 oocytes $(>80 \%)$, but occasionally follicles containing up to 7 oocytes were observed. Follicles with more than 2 oocytes were observed in the FL1 line only.
\end{abstract}

Key words: High fecundity, Mice, Polyovular follicles (POFs)

(J. Reprod. Dev. 56: 449-453, 2010)

I

normal adult mouse ovaries, follicles contain a germ cell sur-

rounded by one or more layers of granulosa cells, according to the follicle developmental stage. However, follicles with more than one oocyte are rarely found [1]. During initial development, multiple germ cells are present within the individualizing follicles, although in most cases, excess cells are eliminated and mammalian ovarian follicles contain only one germ cell per follicle. Follicles with more than one oocyte are referred to as multi oocyte follicles (MOFs) or polyovular follicles (POFs). They have been reported to occur in the ovaries of humans [2], primates [3], dogs [4, 5], cats [6], goats [7] and mice [8]. In rats and mice, the incidence of POFs increases when the animals are exposed to estrogen analogs such as diethylstilbestrol, estradiol benzoate or genistein in a dose-dependent manner $[9,10]$. The POFs observed in mice and humans have been postulated to be remnants of oocyte clusters that did not separate, and which have become enclosed in follicles during neonatal primordial follicle assembly [2, 10, 11].

Fecundity (the number of offspring per litter) can be related to an increase in the number of ova ovulated or in the efficiency of fertilization and embryo development. Booroola sheep have multiple offspring because of an increase in the number of follicles ovulated, which is related to the fecundity gene $F e c B$, a mutation in bone morphogenetic protein receptor IB. The presence of $\mathrm{FecB}$ increases litter size by one or two extra lambs [12]. Polyovular follicles have been especially noted in bitches [13]. The presence of POFs could affect the number of oocytes recovered in assisted reproductive protocols and may also influence the ovulation rate and prolificity of these animals [5].

Previous analysis of fecundity traits revealed that in high fecun-

Received: December 24, 2009

Accepted: April 22, 2010

Published online in J-STAGE: June 6, 2010

(C)2010 by the Society for Reproduction and Development

Correspondence: H Alm (e-mail: alm@fbn-dummerstorf.de) dity mouse lines (FL1, FL2), the number of ova ovulated is higher than the number of corpora lutea (CL) present. This is particularly evident in the FL1 line [14]. This observation suggests that individual follicles release more than one oocyte. The occurrence of polyovular follicles in specific strains of mice has been reported previously [8]. The percentage of animals with POFs as well as the percentage POFs per total follicles varies widely depending on the strain $[10,11]$. However, to our knowledge, the prevalence of POFs in mouse lines of high and low fecundity has not been reported.

In this study, the ovaries of mice after long-term selection for high or normal fecundity were evaluated. The number of follicles of different developmental stages and the frequency of distribution of POFs were determined.

\section{Materials and Methods}

\section{Selective breeding for high and normal fecundity}

Two selected high-fecundity mouse lines (FL1 and FL2) and an inbreeding control line (DUKsi) were produced.

All three mouse lines were originally derived from an outbred line, which was generated by systematic cross-breeding of four inbred (CBA/Bln, AB/Bln, C57BL/Bln, XVII/Bln) and four outbred (NMRI orig., Han:NMRI, CFW, CF1) lines [15, 16]. From this genetic pool, the two independent high-fecundity lines, FL1 and FL2, were selected for an index trait, combining litter size (LSO) and litter weight (LWO) at birth in primiparous females (Index=1.6 $\times$ LSO + LWO) [17] up to generation 126. The estrus cycle of FL2, but not of FL1, females was initially synchronized by application of chlormadinone acetate up to generation 32 .

The control line, DUKsi, was derived from the same initial genetic pool. For 79 generations, a line, DUKs, was kept by random mating and without any selection pressure. In generation 79, line DUKsi was derived from the unselected DUKs line by full sib 
mating with the litter size at birth standardized to 9 pups and weaning to $21 \mathrm{~d}$. The DUKsi females used in the present study were obtained after 36 generations of this selection.

Litter number and weight were recorded for 71, 72 and 65 litters in the DUKsi, FL1 and FL2 lines, respectively, for the generation producing the mice used in this experiment.

All procedures involving animal handling and treatment were approved by the Committee for Animal Use and Care of the Agricultural Ministerial Department of Mecklenburg-Vorpommern, Germany (LALLFMV/TSD/7221.3-1.2-009/6).

\section{Ovary fixation and preparation of slices}

On day 63 after birth, 6 females from different litters from each line were killed by decapitation, and their ovaries were dissected. After determination of their weight, the ovaries were fixed in Bouin's solution, embedded in paraffin wax, serially sectioned (5 $\mu \mathrm{m})$ and aligned in order on glass microscope slides. The sections were stained with hematoxylin and eosin. The evaluation of the slices was performed under an Axio Imager microscope (Zeiss, Germany) at 100 to $400 \times$ magnification.

\section{Classification of the different follicles}

Primordial follicles were identified as having a compact oocyte surrounded by a single layer of flattened granulosa cells, while primary follicles were identified as having an enlarged oocyte (>25 $\mu \mathrm{m}$ diameter) surrounded by a single layer of cuboidal granulosa cells. Secondary follicles were characterized by two or three layers of cuboidal granulosa cells. Tertiary or antral follicles were identified as having an enlarged oocyte ( $\geq 80 \mu \mathrm{m}$ diameter) surrounded by four or more complete layers of cuboidal granulosa cells, and an antrum. Follicles at the different stages of development were classified as atretic if the oocyte was degenerated or fragmented.

\section{Procedure}

Each section of ovary was evaluated, and the number of follicles with two or more oocytes and their developmental stages (primary, secondary, antral) were recorded. Only those follicles containing oocytes with clearly visible nuclei were included in the evaluation to avoid duplication among sections.

\section{Statistical analysis}

The statistical analyses were performed using the Base SAS software, Version 9.1.3, of the SAS System for Windows (Copyright $^{\complement} 2006$ SAS Institute Inc.) [18] and SAS/STAT software, Version 9.1, of the SAS System for Windows (Copyright ${ }^{\circ} 2004$ SAS Institute Inc.) [19]. SAS and all other SAS Institute Inc. products or service names are registered trademarks or trademarks of SAS Institute Inc., Cary, NC, USA.

Elementary statistics and frequency tables were calculated with the help of the MEANS and FREQ procedures. The ovary weight was analyzed by ANOVA using the GLM procedure with the fixed effects of mouse line (DUKsi, FL1, FL2) and site of ovary (left, right) and their interaction in the model. The number of follicles (count data) was analyzed with the GENMOD procedure on the basis of a Poisson regression in a log linear model (1) containing the fixed effects of another mouse line (DUKsi, FL1, FL2) and site
Table 1. Ovary weight (mg) depending on the mouse line

\begin{tabular}{lcr}
\hline Mouse breed & \multicolumn{2}{c}{ Ovary weight $(\mathrm{mg})$ mean \pm SEM } \\
\cline { 2 - 3 } & \multicolumn{1}{c}{ Left ovary } & Right ovary \\
\hline DUKsi & $3.5 \pm 0.9^{\mathrm{a}}$ & $4.4 \pm 0.8^{\mathrm{a}}$ \\
FL2 & $8.4 \pm 0.6^{\mathrm{b}}$ & $9.8 \pm 0.5^{\mathrm{b}}$ \\
FL1 & $11.0 \pm 1.1^{\mathrm{b}}$ & $13.2 \pm 0.9^{\mathrm{c}}$ \\
\hline
\end{tabular}

a, b, c $\mathrm{P}<0.05$ within the columns.

of ovary (left, right) and their interaction and a log linear model (2) containing the fixed effects of mouse line (DUKsi, FL1, FL2) and follicle stage (primary, secondary, antral) and their interaction. Additionally, LS-means and their standard errors (SE) were determined and pair-wise tested (Chi-square test for count data and Tukey-Kramer procedure for continuous data). Data are presented as means \pm SEM and frequencies. Differences with $\mathrm{P}<0.05$ are considered to be significant.

\section{Results}

The mean numbers of pups born per litter for the litters providing the subject animals were $9.92 \pm 2.28,17.33 \pm 2.90$ and $19.17 \pm$ 3.44 for the DUKsi, FL1 and FL2 lines, respectively. The mean total litter weights for these lines were $14.93 \pm 2.64,27.21 \pm 4.58$ and $30.90 \pm 5.45 \mathrm{~g}$, respectively.

We obtained 36 ovaries from the 18 subject animals. Ovarian weight for both the right and left ovaries was significantly lower in the DUKsi line than in the fecund lines; in these lines, the ovary weights were twice (FL2) and three times (FL1) higher than for ovaries from the DUKsi mice (Table 1).

During ovary processing (fixation and embedding in paraffin wax), one ovary from the DUKsi line and two ovaries from the FL2 line were destroyed. Therefore, the whole histology was carried out on 11, 10 and 12 ovaries from DUKsi, FL2 and FL1 lines, respectively.

Polyovular follicles were observed in all three lines. However, the frequency differed among the lines (Table 2). Of 11 ovaries from the DUKsi mice, only 6 follicles from 3 individual mice were found to contain 2 oocytes. Follicles containing more than 2 oocytes were not observed in this line. The follicles containing 2 oocytes were classified in the primary ( 1 follicle), secondary ( 3 follicles) and tertiary/antral (1 follicle) stages. In the FL2 line, 2 oocytes per follicle were found in 19 follicles among 6 individuals. Moreover, more than 2 oocytes per follicle was not observed. Follicles containing 2 oocytes were in the primary ( 2 follicles), secondary (14 follicles) and tertiary (3 follicles) stages. In the FL2 and DUKsi lines the right ovary contained significantly more POFs than the left. Ovaries from the FL1 mice contained significantly more POFs than ovaries from the DUKsi and FL2 lines (mean 27.0 \pm 7.1 ). In contrast to the other stains, there was no significant difference in the occurrence of POFs between the left and right ovaries in the FL1 line. Polyovular follicles were observed in all ovaries collected from the FL1 mice, with some follicles containing up to 7 oocytes per follicle. The mean numbers of follicles with two or more oocytes per ovary for the different lines are shown in 
Table 2. Number of follicles with two or more oocytes per follicle

\begin{tabular}{lcccc}
\hline Mouse breed & $\begin{array}{c}\text { Number of } \\
\text { ovaries }\end{array}$ & \multicolumn{3}{c}{ Number of (\%) follicles with $\geq 2$ oocytes per follicle } \\
\cline { 2 - 5 } & Total & Left ovaries & Right ovaries \\
\hline DUKsi & 11 & 6 & $1(16.7)^{\mathrm{a}}$ & $5(83.3)^{\mathrm{b}}$ \\
FL2 & 10 & 19 & $4(21.0)^{\mathrm{a}}$ & $15(79.0)^{\mathrm{b}}$ \\
FL1 & 12 & 324 & $152(46.9)^{\mathrm{c}}$ & $172(53.1)^{\mathrm{c}}$ \\
\hline
\end{tabular}

a, b, c $\mathrm{P}<0.05$ within the columns and rows.

Table 3. Mean numbers of follicles per ovary with $\geq 2$ oocytes per follicle depending on the mouse breed

\begin{tabular}{lcc}
\hline Mouse breed & Number of ovaries & Mean \pm SEM \\
\hline DUKsi & 11 & $0.6 \pm 0.3^{\mathrm{a}}$ \\
FL2 & 10 & $1.9 \pm 0.7^{\mathrm{a}}$ \\
FL1 & 12 & $27.0 \pm 7.1^{\mathrm{b}}$ \\
\hline
\end{tabular}

a, b $\mathrm{P}<0.05$.

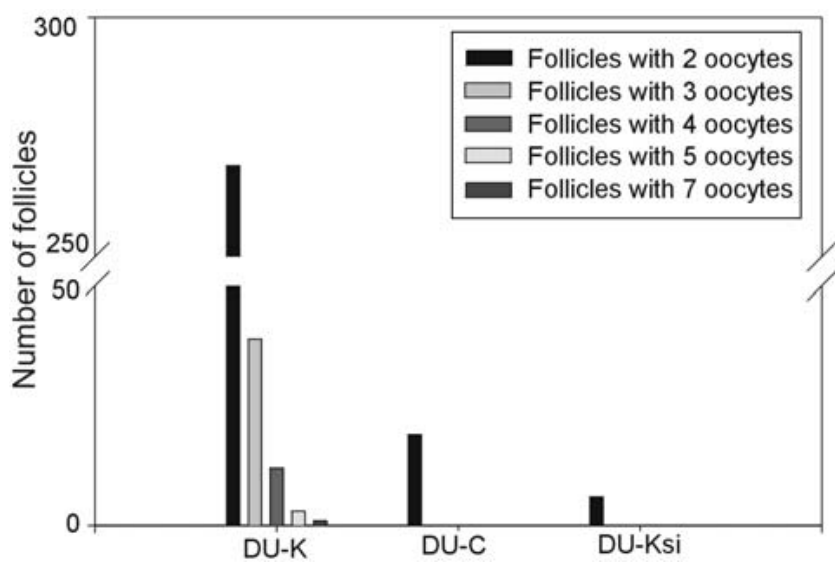

Fig. 1. Distribution of follicles with 2 or more oocytes depending on mouse line.

Table 3.

In the FL1 line, 269 of 324 POFs (83.0\%) contained 2 oocytes (Fig. 1); three oocytes were observed in $12.0 \%$ of the follicles. Four, 5 or 7 oocytes were seen in 3.7, 0.9 and $0.3 \%$ of the follicles, respectively (Fig. 2).

The stages of the follicles containing the POFs for the different lines are presented in Table 4 and Figure 3.

\section{Discussion}

In adult female mice, follicles normally contain one oocyte surrounded by one or more layers of granulosa cells. However, POFs have been observed in the ovaries of mice of specific strains (C58) [8] and in those exposed neonatally to diethylstilbestrol (DES) [20] or other estrogenic compounds [9, 10, 21], which affect both the percentage of animals with POFs and the percentage of follicles that are polyovular. These studies have shown adverse effects on the developing mouse ovary following neonatal exposure to genistein, a phytoestrogen that displays estrogen-like properties, as well as other estrogenic compounds, including $17 \beta$-estradiol, DES and bisphenol A [20, 22]. These observations support the idea that estrogenic substances alter ovarian differentiation by, for example, delaying cyst breakdown and primordial follicle assembly [21, 23]. It is not clear if the estrogen treatment influences the oocyte quality; however, the fertilization rate was reduced in oocytes obtained from multiovular follicles compared with oocytes from uniovular follicles in control and DES-exposed mice [22, 24]. Polyovular follicles are also frequently observed in the ovaries of isoflavone treated mice [25]. An average of $11.3 \pm 1.5$ POFs per ovary was found on postnatal day 21 in the treated animals compared with 1.0 \pm 0 for the controls.

In the present study, we observed POFs after long-term selection for high fecundity.

Primary POFs show a single, cuboid granulosa layer surrounded by the basement membrane and a connective tissue sheath, as observed for follicles containing a single oocyte. In secondary follicles, an increase in the number of cells of the granulosa layer is observed along with a homogeneous glycoprotein layer - the zona pellucida-around each oocyte and a well defined thecal sheath. Antral follicles show a multilayered granulosa lining the antrum, and oocytes assumed central but separate positions, demonstrating a dome-like protrusion-the cumulus hillock-in each one.

In the present study, most of the POFs contained two to three oocytes, but in some cases, follicles containing up to seven oocytes were observed. Follicles with a high number of oocytes (more than

Table 4. Distribution of follicles with two or more oocytes depending on the follicle development

\begin{tabular}{lccccc}
\hline $\begin{array}{l}\text { Mouse } \\
\text { breed }\end{array}$ & $\begin{array}{c}\text { Number of } \\
\text { ovaries }\end{array}$ & $\begin{array}{c}\text { Number of follicles } \\
\text { with } \geq 2 \text { oocytes }\end{array}$ & \multicolumn{3}{c}{ Follicle stages n (\%) } \\
\cline { 4 - 6 } DUKsi & 11 & 6 & $1(16.7)$ & $3(50.0)$ & $2(33.3)$ \\
FL2 & 10 & 19 & $2(10.5)$ & $14(73.7)^{\text {a }}$ & $3(15.8)$ \\
FL1 & 12 & 324 & $72(22.2)$ & $151(46.6)^{\mathrm{b}}$ & $101(31.2)$ \\
\hline
\end{tabular}

a, b $\mathrm{P}<0.05$. 

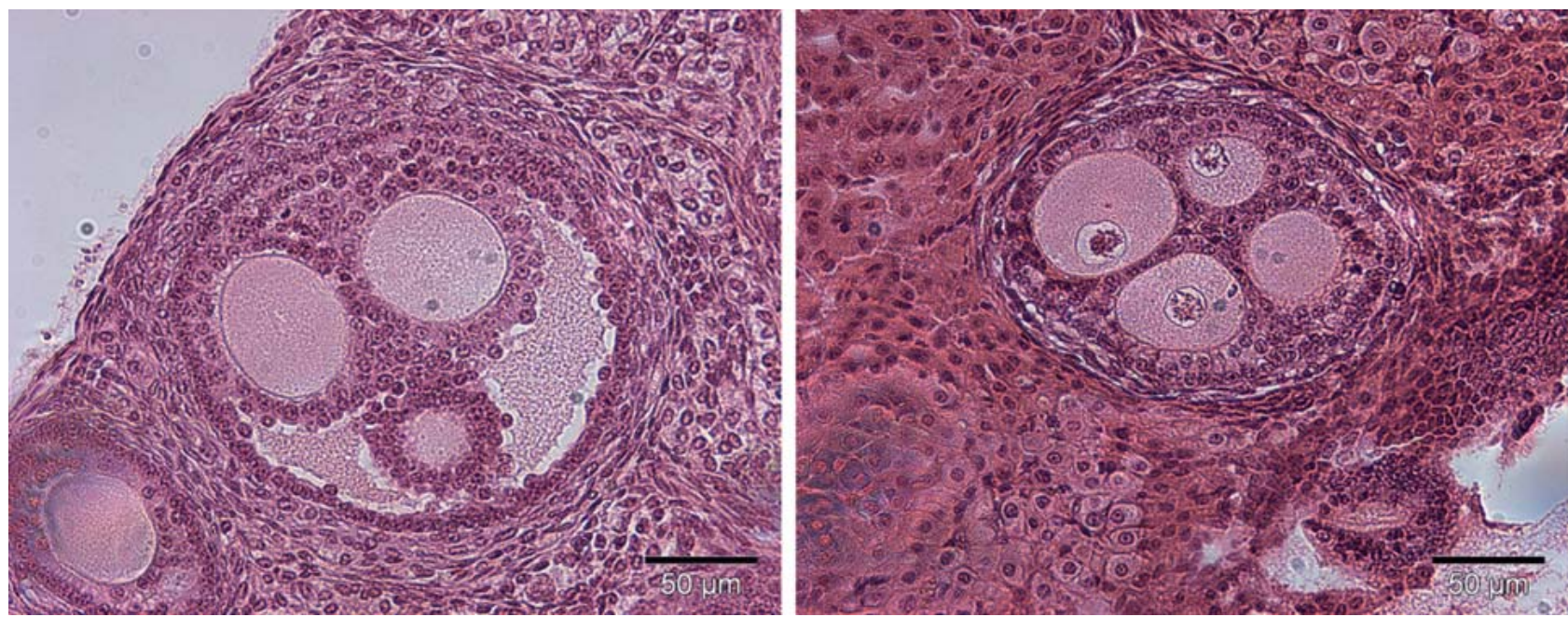

Fig. 2. Multi-oocyte follicles in the mouse: antral follicle with 3 oocytes (left); secondary follicle with 4 oocytes (right). Scale bars=50 $\mu \mathrm{m}$.

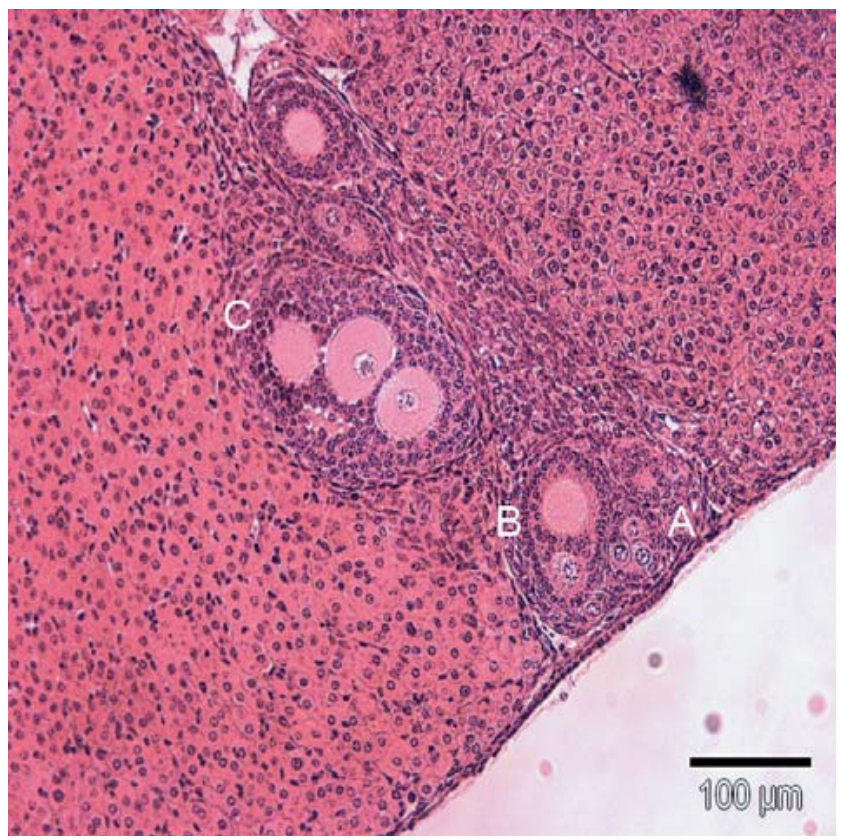

Fig. 3. Multi-oocyte follicles of the mouse. A: Primary follicle with 3 oocytes. B: Secondary follicle with 2 oocytes. C: Early antral follicle with 3 oocytes. Scale bar=100 $\mu \mathrm{m}$.

five) have also been observed in ovaries of domestic dogs [5, 13]. In dogs, the prevalence of POFs (mostly 2 to 3 ) was higher in young animals (under one year: 68\%) than in old animals (10 year old bitches: 14\%). The developmental potential of these follicles is unclear, but the existence of preovulatory polyovular follicles has been reported [26].

The presence of polyovular antral follicles of ovulatory diameter suggests that POFs do ovulate. An earlier study in dogs [27], in which more oocytes/embryos were collected in oviductal flushings than the number of corpora lutea counted, also supports the ovulation of polyovular follicles. In previous studies with the same mice lines as we used, it was reported that the number of ova released into the oviduct was considerably higher in the FL1 line than in the FL2 line. However, the loss rate of ova and of pre- and post implantation conceptuses was lower in FL2, thus resulting in the highest prolificacy performance in this line [14].

The origin of POFs is not clear. Although effects of estrogenic compounds have been known for many years, the mechanism by which POFs form is unknown $[10,11]$. It has been proposed that they may derive from failure of germ cell breakdown during early stages of folliculogenesis, or from rapid development of germ cells compared with the differentiation of the surrounding somatic cells, resulting in the inclusion of several germ cells within a follicle [6].

Furthermore, there are two mammalian estrogen receptors, ER $\alpha$ and $\operatorname{ER} \beta$, with multiple roles in female reproduction [28]. POFs observed with genistein treatment are still observed in ER $\alpha$ mutant mice but are not observed in $\mathrm{ER} \beta$ mutant mice, suggesting that the effects of genistein are mediated through $\mathrm{ER} \beta$ [9]. In the present study, the animals were free of steroid influence, and the different lines of mice were raised in similar environments. Therefore, it is unlikely that our findings were affected by the effects of environmental estrogen.

\section{Acknowledgments}

The authors thank Prof Dr K Hinrichs, Texas A\&M University, for review of the manuscript and B Drawert and C Meyer for excellent technical assistance. 


\section{References}

1. Kent HA. Polyovular follicles and multinucleate ova in the ovaries of young mice. Anat Rec 1960; 137: 521-524.

2. Gougeon A. Frequent occurrence of multiovular follicles and multinuclear oocytes in the adult human ovary. Fertil Steril 1981; 35: 417-422.

3. Gougeon A. Regulation of ovarian follicular development in primate: Fact and hypotheses. Endocr Rev 1996: 17: 121-155.

4. McDougall K, Hay MA, Goodrowe KL, Gartley CJ, King WA. Changes in the number of follicles and of oocytes in ovaries of prepubertal, peripubertal and mature bitches. J Reprod Fert 1997; 51 (Suppl): 25-31.

5. Payan-Carreira R, Pires MA. Multioocyte follicles in domestic dogs: A survey of frequency of occurrence. Theriogenology 2008; 69: 977-982.

6. Bristol-Gould S, Woodruff TK. Folliculogenesis in the domestic cat (felis catus). Theriogenology 2006; 66: 5-13.

7. Lucci CM, Amorim CA, Rodrigues APR, Figueiredo JR, Bao SN, Silva JR, Goncalves PBD. Study of preantral follicle population in situ and after mechanical isolation from caprine ovaries at different reproductive stages. Anim Reprod Sci 1999; 56: 223-236.

8. Fekete E. Polyovular follicles in the C58 strain of mice. Anat Rec 1950; 108: 699-707

9. Jefferson WN, Couse JF, Padilla-Banks E, Korach KS, Newbold RR. Neonatal exposure to genistein induces estrogen receptor (ER) alpha expression and multioocyte follicles in the maturing mouse ovary: evidence for ERbeta-mediated and nonestrogenic actions. Biol Reprod 2002; 67: 1285-1296.

10. Iguchi T, Takasugi N, Bern HA, Mills KT. Frequent occurrence of polyovular follicles in ovaries of mice exposed neonatally to diethylstilbestrol. Teratology 1986; 34: 29_ 35

11. Iguchi T, Takasugi $\mathbf{N}$. Polyovular follicles in the ovary of immature mice exposed prenatally to diethylstilbestrol. Anat Embryol (Berl) 1986; 175: 53-55.

12. Wilson T, Wu XY, Juengel JL, Ross IK, Lumsden JM, Lord EA, Dodds KG, Walling GA, McEwan JC, O'connell AR, McNatty KP, Montgomery GW. Highly prolific Booroola sheep have a mutation in the intracellular kinase domain of bone morphogenic protein IB receptor (Alk-6) that is expressed in both oocytes and granulose cells. Biol Reprod 2001; 64: 1225-1235.

13. Telfer E, Gosden RG. A quantitative cytological study of polyovular follicles in mammalian ovaries with particular refrence to the domestic bitch (Canis familiaris). J Reprod Fert 1987; 81: 137-147.
14. Spitschak M, Langhammer M, Schneider F, Renne U, Vanselow J. Two high-fertility mouse lines show differences in component fertility traits after long-term selection. Reprod Fert Dev 2007; 19: 815-821.

15. Dietl G, Langhammer M, Renne U. Model simulations for genetic random drift in the outbred strain Fzt : DU. Arch Anim Breeding 2004; 47: 595-604.

16. Schüler L. Selection for fertility in mice: the selection plateau and how to overcome it Theor Appl Genet 1985; 70: 72-79.

17. Schüler L, Bünger L. Die reproduktive Lebensleistung selektierter Labormauslinien Arch Tierzucht 1982; 25: 275-281.

18. SAS Institute Inc. 2006. Base $S A S^{\circledast}$ 9.1.3 Procedures Guide, 2nd ed, Edition, Volumes 1 2, 3, and 4. Cary, NC: SAS Institute Inc.

19. SAS Institute Inc. 2004. SAS/STAT.9.1 User's Guide. Cary, NC: SAS Institute Inc.

20. Suzuki A, Sugihara A, Uchida K, Sato T, Ohta Y, Katsu Y, Watanabe H, Iguchi T Developmental effect of perinatal exposure to bisphenol-A and diethylstilbestrol on reproductive organs in female mice. Reprod Toxicol 2002; 16: 107-116.

21. Jefferson WN, Newbold RR, Padilla-Banks E, Pepling M. Neonatal genistein treatment alters ovarian differentiation in the mouse: inhibition of oocyte nest breakdown and increased oocyte survival. Biol Reprod 2006; 74: 161-168.

22. Iguchi T, Fukazawa Y, Uesugi Y, Takasugi N. Polyovular follicles in mouse ovaries exposed neonatally to diethylstilbestrol in vivo and in vitro. Biol Reprod 1990; 43: 478484

23. Chen Y, Jefferson WN, Newbold RR, Padilla-Banks E, Pepling ME. Estradiol, progesterone, and genistein inhibit oocyte nest breakdown and primordial follicle assembly in the neonatal mouse ovary in vitro and in vivo. Endocrinology $2007 ; 148$ : 3580-3590.

24. Iguchi T, Kamiya K, Uesugi Y, Sayama K, Takasugi N. In vitro fertilization of oocyte from polyovular follicles in mouse ovaries exposed neonatally to diethylstilbestrol. In vivo 1991; 5: 359-363.

25. Takashima-Sasaki K, Komiyama M, Adachi T, Sakurai K, Kato H, Iguchi T, Mori C Effect of exposure to high isoflavone-containing diets on prenatal and postnatal offspring mice. Biosci Biotechnol Biochem 2006; 70: 2874-2882.

26. Andersen AC, Simpson ME. The Ovary and the Reproductive Cycle of the Dog (Beagle). Geron-X Inc., Los Altos, California, 1973.

27. Reynaud K, Viaris de Lesengo C, Chebrout M, Thoumire S, Chastant-Maillard S Follicle population, cumulus mucification, and oocyte chromatin configuration during the periovulatory period in the female dog. Theriogenology 2009; 72: 1120-1131.

28. Britt KL, Findlay JK. Estrogen actions in the ovary revisited. Endocrinology 2002; 175 268-276. 